\title{
PLANT PROTECTION EXPERIENCES IN GRAPE YARDS IN 2012
}

\author{
János ÁGOSTON ${ }^{*}$ \\ ${ }^{1}$ John von Neumann University, Faulty of Horticulture and Rural Development, Department of Agriculture. \\ 6000 Kecskemét, Mészöly Gyula tér 1-3., Hungary \\ https://doi.org/10.47833/2020.1.AGR.004
}

Keywords:
Plasmopara viticola
Guignardia bidwellii
Arabis mosaic virus
'Candidatus Phytoplasma solani'
Drepanothrips reuteri

Article history:

Received 25 Nov 2019

Revised 15 Nov 2019

Accepted 20 Nov 2019

\begin{abstract}
Grape is the most important fruit bearing crop in Hungary. It's growing area was 20680 ha in 2012 in Bács-Kiskun County, which is $2,4487 \%$ of the total area of the county. In this paper I describe the plant protection experiences in grape yards in 2012.
\end{abstract}

\section{Introduction}

Grape is the most important fruit bearing crop in Hungary. Production costs increase while sale prices decrease year by year. This situation threatens economical grape production. It is indispensable to choose the exact time and material for plant protection in order to make grape production more profitable.

Grape growing area was 20680 ha in 2012 in Bács-Kiskun County, which is 2,4487\% of the total area of the county. The crop is not evenly distributed. In the districts Kiskörös and Kalocsa more than $50 \%$ of the area of agricultural crops is grape, this is $20-30 \%$ in Kecskemét and Jánoshalma, and the rest of the districts have 10-20\%.

As it is a major crop, both its technology and disease management is well developed. The 3 main pillars of the protection of grape from pathogens are the protection against downy mildew (Plasmopara viticola), powdery mildew (Erysiphe necator) and grey mould (Botrytis cinerea) [1, 4$7,11,12,14]$. This 3 pathogen is present in all grape yards, and can cause problems depending on the weather.

In the case of downy mildew the symptoms change in the second part of the season, instead of roundish spots, longitudinal or rectangular, tapestry-like spots develop between the veinlets [11]. If symptoms in spring develop on the upper side of the canopy then the infection is "carried in" by winds [3].

The main grape viruses, like Arabis mosaic virus, are transmitted by nematodes $[4,5]$.

Within the pests grape moths (Sparganothis pilleriana, Lobesia botrana, Eupoecelia ambiguella) are the most dangerous [9-11], but Scaphoideus titanus is also an important pest since it's appearance in 2007 [2, 15], as it is the main vector of the quarantine disease 'Candidatus Phytoplasma vitis'.

Little less significant disease is the black rot (Guignardia bidwellii) $[4,5,11]$ which can cause damage depending on the weather, and a lesser known pest, grape thrips (Drepanothrips reuteri) [8].

The weather of 2012 was very extreme. Only February's and December's monthly average temperature was below the many years average. In February 4 days' daily minimum temperature

\footnotetext{
* Corresponding author. Tel.: +36 76517726

E-mail address: agoston.janos@kvk.uni-neumann.hu
} 
was below $-18^{\circ} \mathrm{C}$; the monthly average temperature was $-4,43{ }^{\circ} \mathrm{C}$ lower than the many years average. There were also frost damages in April. In Kecskemét-Hetényegyháza on the $2^{\text {nd }}$ of April there was $-6^{\circ} \mathrm{C}$, and $-10,6^{\circ} \mathrm{C}$ on the $10^{\text {th }}$. These conditions had a major adverse effect on the growth of grapes. Because of the severe cold of February, trunks, cordons and canes suffered frost damage; in April the freshly emerging shoots died. In spite of all these cold days the yearly average temperature was $+1,49^{\circ} \mathrm{C}$ higher than the many years average.

In the case of precipitation the situation was no different. There was barely any precipitation in March and August; but in September almost twice the amount of the many years average fell. Still the yearly sum of precipitation was $82 \mathrm{~mm}$ less, than the many years average.

\section{Method}

Experiments and observations were made in Bács-Kiskun County. Host plant phenology and disease data were retrieved from the Plant Protection Information System (NIR) [13] and from the reports of district plant protection inspectors of the Government Office of Bács-Kiskun County, the observations of Gábor Mező, Tamas Hegyi and the author.

The reporting of pest severity was carried out by the protocols of EPPO and Agricultural Administrative Agency (MGSZH) [16-19].

\section{Results}

The first report of downy mildew was on the $6^{\text {th }}$ of June, both on the foliage and on the fruit bunch. According to the meteorological data Oospores should have been germinated on the $5^{\text {th }}$ of May, and leaf symptoms should have been appeared on the $22^{\text {nd }}$ of May. Based on these, and that the symptoms appeared simultaneously on the vegetative and generative parts of the grape the downy mildew was "carried in".

The pest occurrence and severity was also lower than usual. In the second half of June in Bács-Kiskun, Tolna and Somogy counties the pest occurrence was low, below $5 \%$. In Csongrád and Zala counties only 1 district showed mild occurrence, the rest of the country was virtually free of infection.

From Kiskörös a grower brought samples of unusual leaf symptoms in September. The leaves showed 1-2 mm wide, necrotic, angular leaf spots bordered by veinlets. When the severity reached $20-25 \%$ the leaves turned yellow and defoliation occurred. The symptoms were pronounced on the cultivar Bianca, but other downy mildew resistant cultivars showed similar symptoms. Leaf samples were examined in the Pest Diagnostic Laboratory of the Government Office of Bács-Kiskun County by the author. Scrapings were made from the underside of the leaves after incubation in damp chamber for 24 to 48 hours. During the microscopic examination specific sporangiophores and sporangia of Plasmopara viticola were observed.

The other type of samples showed necrosis of the fruit bunch; irregular, light brown necrosis of leaf tissue with brown margins, were observed regardless of cultivar. The necrotic parts - both on the fruit bunch and on the leaf - small black spots appeared. After incubation the microscopic examination revealed the black spots were the pycnidia of the pathogen, which released masses of conidia. After the examination of conidia, pycnidia and the present symptoms Guignardia bidwellii was identified as the causal agent.

During the scouting of grape yards in Kiskörös we have spotted a few poorly developed plants. They showed yellow chlorosis along the veins; fruit set was low or inconsistent. Symptoms were consistent with the viral stunting of grape. Samples were collected and sent for ELISA testing to the pest diagnostic laboratory of the National Food Chain Safety Office. The presence of Arabis mosaic virus were detected in all samples.

The obligatory inspection of grapes for grapevine flavescence dorée resulted in the collection of symptomatic leaves of plants. All presumably infected plants were sampled and sent to the pest diagnostic laboratory of the National Food Chain Safety Office. All samples were infected with 'Candidatus Phytoplasma solani'. This disease has identical symptoms as the quarantine pest 'Candidatus Phytoplasma vitis', and can only be distinguished by molecular means.

The scouting for the vector of this disease we have found specimens of Drepanothrips reuteri, which causes similar damage to Scaphoideus titanus. 


\section{Discussion}

While downy mildew is present in all gape yards, in 2012 the disease was "carried in". One possible reason for this is that the Oospores of the pathogen have not survived the severe cold in winter and spring. This observation coincides with former reports and references.

Guignardia bidwelli and Arabis mosaic virus are lesser known pathogens of grape, but can cause serious damage if left unattended.

Drepanothrips reuteri is present in Hungarian grape yards, it causes similar damage to Calepitrimerus vitis in spring and to Scaphoideus titanus in summer.

\section{Conclusions}

Growers should be aware of the signs and symptoms of the most common pests and diseases of grapes.

It is also very important that growers scout regularly for the presence of quarantine pests, and report their suspicion to the authorities. It is in our common interest to keep our plantations in good health and prevent the spread of quarantine and major pests.

In near vicinity of neglected orchards one have to expect higher pressure of pests and diseases, and under favorable conditions lesser known pathogens may cause economically significant damage.

\section{Acknowledgment}

l'd like to express my gratitude towards Gábor Mező, Tamás Hegyi for their observation, Edit Szücs for NIR and meteorological data, and her help in assessment of the trials and her assistance in the laboratory.

Thank you for the support of the research carried out in the framework of the EFOP-3.6.2-162017-00012 „Developing a functional, healthy and safe food product chain model from field to table in a thematic research network". The project is funded by the Hungarian State and the European Union, co-financed by the European Social Fund, and is part of the Széchenyi 2020 program.

\section{References}

[1] Brooks A., Halstead A., Royal Horticultural Society (1999) Garden pests and diseases. Mitchell Beazley, London. ISBN: 978-1-84000-155-6.

[2] Dér Zs., Koczor S., Zsolnai B., Ember I., Kölber M., Bertaccini A., Alma A. (2007) Scaphoideus titanus identified in Hungary. Bulletin of Insectology 60:199-200.

[3] Gáspár I., Novák J., Pecze R. (1996) Lehetett-e szállított inokulum az 1995. évi szőlőperonoszpóra-fertőzés oka Bács-Kiskun megyében? Agrofórum 7:55-56.

[4] Glits M., Folk Gy. (1997) Kertészeti növénykórtan. Mezőgazda Kiadó, Budapest. ISBN: 978-963-7362-69-9.

[5] Glits M., Folk Gy. (2007) Kertészeti növénykórtan. Mezőgazda Kiadó, Budapest. ISBN: 978-963-286-297-2.

[6] Glits M., Horváth J., Kuroli G., Petróczi I. (eds) (1997) Növényvédelem. Mezőgazda Kiadó, Budapest. ISBN: 978963-286-042-8.

[7] Hluchý M., Ackermann P., Zacharda M., Laštůvka Z., Bagar M., Jetmarová E., Gáspár V., Szőke L., Plíšek B. (2007) A gyümölcsfák és a szőlő betegségei és kártevői. Biocont Laboratory Ltd. Brno-Slatina, CZ, Brno. ISBN: 978-80-901874-9-8.

[8] Jenser G. (1988) Rend: Tripszek - Thysanoptera. In: Jermy T, Balázs K (eds) A Növényvédelmi állattan kézikönyve 1. Akadémiai Kiadó, Budapest. pp. 283-305. ISBN: 978-963-05-4707-4.

[9] Jermy T., Balázs K. (eds) (1993) A Növényvédelmi állattan kézikönyve 4/A. Akadémiai Kiadó, Budapest. ISBN: 978-963-05-5741-X.

[10] Jermy T., Balázs K. (eds) (1993) A Növényvédelmi állattan kézikönyve 4/B. Akadémiai Kiadó, Budapest. ISBN: 978-963-05-4706-2.

[11] Lehoczky J., Reichart G. (1968) A szőlő védelme. Mezőgazdasági Kiadó, Budapest.

[12] Mező G. (1995) Szőlőperonoszpóra járvány Bács-Kiskun megyében 1995-ben. Növényvédelem 31:593-595

[13] Növény és Talajvédelmi Állomás (1990) NIR: Növényvédelmi Információs Rendszer. Növény és Talajvédelmi Állomás, Budapest.

[14] Vétek G., Nagy G. (2011) Kártevők és kórokozók a kertben: károsítók azonosítása és a védekezés lehetőségei. Cser Kiadó, Budapest. ISBN: 978-963-278-208-9.

[15] Zsolnai B., Orosz Sz. (2013) A Scaphoideus titanus Ball jelenlegi helyzete Magyarországon. Georgikon for agriculture: A multidisciplinary journal in agricultural sciences 16:124-125.

[16] (2004) Általános vizsgálati módszertan. Mezőgazdasági Szakigazgatási Hivatal, Budapest. 
[17] (2012) Conduct and reporting of efficacy evaluation trials, including good experimental practice. EPPO Bulletin 42:382-393. DOI: 10.1111/epp.2611

[18] (2004) Fungicid és baktericid vizsgálati módszertan. Mezőgazdasági Szakigazgatási Hivatal, Budapest.

[19] (2001) Plasmopara viticola. EPPO Bulletin 31:313-317. DOI: 10.1111/j.1365-2338.2001.tb01000.x 